\title{
Restricted feeding and linseed oil as modifiers of the fatty acid profile in pork
}

\author{
J. Więcek ${ }^{1}$ and J. Skomial ${ }^{2.3}$ \\ Warsaw Agricultural University, \\ 'Department of Pig Breeding, \\ 'Department of Animal Nutrition and Feed Science \\ Ciszewskiego 8, 02-786 Warsaw; Poland \\ ${ }^{3}$ The Kielanowski Institute of Animal Physiology and Nutrition. Polish Academy of Sciences \\ 05-110 Jablonna. Poland
}

\begin{abstract}
Thirty-two fatteners were divided into 4 groups: two of them were fed semi ad libitum (A) during the growing $(22-60 \mathrm{~kg})$ and finishing $(60-102 \mathrm{~kg})$ periods of fattening and two, a restricted $(-25 \%)$ amount of feed $(\mathrm{R})$ in the growing period and semi ad libitum in the finishing period. During the finishing period within each level of feeding, one group received 0 ( $A C$ and $R C$ ) and the other $4 \%$ (AO and $\mathrm{RO}$ ) linseed oil. Pigs fed the restricted amount of feed had a more beneficial fatty acid profile in the $M$. longissimus dorsi and $M$. semimembranosus, however, the differences were not statistically significant. The $4 \%$ supplement of linseed oil in the finishing diets caused an increase in the PUFA content, of n-3 in particular.
\end{abstract}

KEY WORDS: fatteners, restricted fecding, linsecd oil, carcass, fatty acid

\section{INTRODUCTION}

The main criteria for evaluating the functional properties of pork are its total fat and cholesterol contents and fatty acid profile. The SFA, MUFA and PUFA ratios are the most important (Wood et al., 2003). It is known that the fat content in pork increases most in the finishing period of fattening and that the composition of the feedstuff can influence the fatty acid profile of pork. The aim of the study was to evaluate the influence of restricted feeding during the growing period of fattening and linseed oil supplementation in finishing diets on the fatty acid profile of pork.

\footnotetext{
$\overline{1}$ Corresponding author: e-mail: wiecek@delta.sggw.waw.pl
} 


\section{MATERIAL AND METHODS}

Thirty-two fattencrs were divided into 4 groups: two of them were fed semi ad libitum (A) during the growing (22-60 kg) and finishing $(60-102 \mathrm{~kg})$ periods of fattening and two, restricted $(-25 \%)$ amounts of feed $(\mathrm{R})$ in the growing period and semi ad libitum in the finishing period. Within each level of feeding, during the finishing period one group received 0 ( $A C$ and $R C^{\prime}$ ) and the other $4 \%$ ( $A O$ and $R O$ ) linseed oil. The composition and nutritive value of the experimental diets are shown in Table 1.

TABLE 1

Composition (\%) and nutritive value of feed mixtures in the growing and finishing periods

\begin{tabular}{lccc}
\hline \multirow{2}{*}{ Item } & \multirow{2}{*}{ Growing period } & \multicolumn{2}{c}{ Finishing period } \\
\cline { 2 - 4 } & & 19.00 & Group 0 \\
\hline Ground wheat & 18.00 & 66.61 & 19.00 \\
Ground barley & 59.25 & - & 60.93 \\
Wheat bran & 3.00 & 11.80 & - \\
Soyabcan meal & 17.20 & - & 13.20 \\
L.inseed oil & - & - & 4.00 \\
Vitamin E & - & 2.25 & 0.30 \\
Mineral-vitamin mix & 2.20 & 0.24 & 2.25 \\
L-lysinc & 0.27 & 0.04 & 0.22 \\
DL-methionine & 0.09 & 0.06 & 0.04 \\
L-threonine & 0.09 & 12.5 & 0.06 \\
ME, MJ/1 kg & 12.5 & 134.3 & 13.5 \\
Crude protein, g/1 kg & 153.4 & & 146.6 \\
\hline
\end{tabular}

After slaughter, samples of the $M$. longissimus dorsi (13-14 rib) and of the $M$. semimembranosus from the right half-carcasses of all of the animals were taken to determine the fatty acid profile (ISO 5509, 1978 and ISO 5508, 1990). The results were subjected to one-way analysis of variance employing Duncan's multiple range test (SPSS, 2000).

\section{RESULTS}

The lipid fraction of the $M$. longissimus dorsi from fatteners from groups $\mathrm{AO}$ and $\mathrm{RO}$ contained, in comparison with $\mathrm{AC}$ and $\mathrm{RC}$, a larger amount of SFA (differences were not significant) and PUFA n-3 ( $\mathrm{P} \leq 0.001)$, but in the lipid fraction of the $M$. semimembranosus, these differences concerned both PUFA $\mathrm{n}-6$ and PUFA $\mathrm{n}-3$ were significant $(\mathrm{P} \leq 0.001)$. Supplementation of the diets with linseed oil narrowed the PUFA n-6:PUFA n-3 ratio. A more beneficial fatty acid profile, PUFA n-6:PUFA n-3, and PUFA:SFA ratios were found in fatteners fed restricted amounts of feed in the growing period of fattening in comparison with fatteners fed semi ad libitum during the whole fattening period. 
TABLE 2

Fatty acid profile, \% of sum of fatty acids

\begin{tabular}{|c|c|c|c|c|c|c|c|c|c|c|c|}
\hline \multirow{2}{*}{$\begin{array}{l}\text { Group } \\
\text { Itcm }\end{array}$} & \multicolumn{11}{|c|}{ Falty acid } \\
\hline & $14: 0$ & $16: 0$ & $16: 1$ & $18: 0$ & $18: 1$ & $18: 2$ & $18: 3$ & $20: 4$ & $20: 5$ & $22: 4$ & $22: 6$ \\
\hline \multicolumn{12}{|c|}{ M. longissimus dorsi } \\
\hline $\mathrm{AC}$ & 1.32 & 25.57 & 4.17 & 12.86 & 46.77 & 6.58 & 0.40 & 1.58 & 0.16 & 0.33 & 0.28 \\
\hline $\mathrm{AO}$ & 1.38 & 25.57 & 3.90 & 13.08 & 45.14 & 6.78 & 2.22 & 0.90 & 0.39 & 0.19 & 0.46 \\
\hline $\mathrm{RC}$ & 1.29 & 25.26 & 4.27 & 12.03 & 46.08 & 7.71 & 0.47 & 1.93 & 0.19 & 0.40 & 0.38 \\
\hline RO & 1.30 & 24.75 & 3.70 & 13.14 & 44.58 & 7.79 & 2.31 & 1.20 & 0.48 & 0.20 & 0.57 \\
\hline $\mathrm{Se}$ & 0.020 & 0.117 & 0.076 & 0.131 & 0.378 & 0.324 & 0.062 & 0.100 & 0.025 & 0.022 & 0.029 \\
\hline $\mathrm{p}$ & NS & NS & $\mathrm{NS}$ & 0.021 & $\mathrm{NS}$ & NS & 0.001 & 0.006 & 0.001 & 0.005 & 0.012 \\
\hline \multicolumn{12}{|c|}{ M. semimembranosus } \\
\hline $\mathrm{AC}$ & 1.33 & 24.29 & 4.01 & 12.53 & 49.72 & 6.14 & 0.49 & 0.96 & 0.12 & 0.23 & 0.18 \\
\hline $\mathrm{AO}$ & 1.29 & 23.90 & 3.68 & 12.49 & 45.26 & 8.29 & 3,15 & 0.95 & 0.38 & 0.18 & 0.45 \\
\hline$R C^{*}$ & 1.29 & 24.22 & 4.24 & 11.46 & 47.15 & 8.26 & 0.58 & 1.93 & 0.17 & 0.37 & 0.34 \\
\hline $\mathrm{RO}$ & 1.26 & 23.50 & 3.38 & 12.55 & 43.41 & 10.22 & 3,39 & 1.16 & 0.43 & 0.20 & 0.51 \\
\hline $\mathrm{Se}$ & 0.013 & 0.088 & 0.062 & 0.130 & 0.389 & 0.250 & 0.071 & 0.093 & 0.025 & 0.020 & 0.025 \\
\hline \multirow[t]{2}{*}{$\mathrm{p}$} & NS & 0.013 & 0.001 & 0.013 & 0.001 & 0.001 & 0.001 & 0.002 & 0.001 & 0.009 & 0.001 \\
\hline & \multicolumn{2}{|l|}{ SFA } & MLFA & \multicolumn{2}{|c|}{ PUFA n-6 } & \multicolumn{2}{|c|}{ PLFA n-3 } & \multicolumn{2}{|c|}{ PUFA n-6/n-3 } & \multicolumn{2}{|c|}{ PUFA/SFA } \\
\hline \multicolumn{12}{|c|}{ M. longissimus dorsi } \\
\hline $\mathrm{AC}$ & \multicolumn{2}{|c|}{39.75} & 50.93 & \multicolumn{2}{|r|}{8.49} & \multicolumn{2}{|c|}{0.83} & \multicolumn{2}{|c|}{10.38} & \multicolumn{2}{|c|}{0.24} \\
\hline $\mathrm{AO}$ & \multicolumn{2}{|c|}{40.03} & 49.04 & \multicolumn{2}{|r|}{7.87} & \multicolumn{2}{|c|}{3.06} & \multicolumn{2}{|c|}{2.56} & \multicolumn{2}{|c|}{0.28} \\
\hline $\mathbf{R C}$ & \multicolumn{2}{|c|}{38.58} & 50.35 & \multicolumn{2}{|c|}{10.04} & \multicolumn{2}{|c|}{1.03} & \multicolumn{2}{|c|}{9.83} & \multicolumn{2}{|c|}{0.29} \\
\hline RO & \multicolumn{2}{|c|}{39.19} & 48.27 & \multicolumn{2}{|r|}{9.18} & & .36 & & .73 & & 32 \\
\hline $\mathrm{Se}$ & 0.20 & & 0.426 & & 0.433 & & .112 & & .137 & & .014 \\
\hline p & NS & & NS & & NS & & .001 & & .001 & & NS \\
\hline M. sen & membran & losus & & & & & & & & & \\
\hline $\mathrm{AC}$ & 38.15 & & 53.73 & & 7.32 & & .79 & & .48 & & .21 \\
\hline $\mathrm{AO}$ & 37.68 & & 48.94 & & 9.41 & & .98 & & .36 & & .36 \\
\hline $\mathbf{R C}$ & 36.97 & & 51.39 & & 10.56 & & .08 & & .85 & & .32 \\
\hline RO & 37.30 & & 46.79 & & 11.58 & & 34 & & .68 & & .43 \\
\hline $\mathrm{Se}$ & 0.18 & & 0.395 & & 0.332 & & 0.091 & & .158 & & 0.011 \\
\hline $\mathrm{p}$ & NS & & 0.001 & & 0.001 & & 0.001 & & .001 & & .001 \\
\hline
\end{tabular}

\section{DISCUSSION}

Numerous experiments have demonstrated that there is a close correlation between the quantity of fatty acids in feed and in the lipid fraction of pork (Nguyen et al., 2003). Increasing PUFA $n-3$ in a diet by adding fish oil or vegetable oil, particularly linseed oil, can beneficially affect the lipid composition of pork (Muriel et al., 2002; Raes et al., 2004); the PUFA n-6/n-3 ratio can even be decreased to under the value of 3 (Enser et 
al., 2000). Compensatory growth can change fat deposition in the finishing period, and when oil containing more PUFA is fed during this period, the fatty acid profile can be improved.

\section{CONCLUSIONS}

Linseed oil-supplemented diets beneficially influenced the fatty acid profile in pork fat. Restricted feeding itself does not markedly influence the fatty acid profile, but when linseed oil is fed in the finishing period of fattening, an increase in PUFA incorporated into the fat from the diet was observed.

\section{REFERENCES}

Enser M., Richardson R.I., Wood J.D., Gill B.P., Sheard P.R., 2000. Feeding linseed to increase the n-3 PUFA of pork: fatty acid composition of muscle, adipose tissue, liver and sausages. Meat Sci. 55, 201-212

ISO, 5508, 1990. Animal and vegetable fats and oils-Analysis by gas chromatography of methyl esters of fats acids

ISO, 5509, 1978. Animal and vegetable fats and oils-Preparation of methyl esters of fatty acids

Muricl E.. Ruiz J., Ventanas J., Antequera T., 2002. Free-range rearing increases (n-3) polyunsaturated fatty acids of neutral and polar lipids in swine muscles. Food Chem. 78, 219-225

Nguyen L.Q., Nuijens M.C.(i.A., Fverts II., Salden N., Beynen A.C., 2003. Mathematical relationships between the intake of $n-6$ and $n-3$ polyunsaturated fatty acids and their contents in adipose tissue of growing pigs. Meat Sci. 65, 1399-1406

Raes K., de Smet S., Demeyer D., 2004. Effect of dietary fatty acids on incorporation of Iong chain polyunsaturated fatty acids and conjugated linoleic acids in lamb, beef and pork meat: a review. Anim. Feed Sci. Tech. 113, 199-221

SPSS, 2000. SPSS 10.0 for Windows user's Guide, by SPSS Ins. (USA)

Wood J.D., Richardson R.I., Nute G.R., Fisher A.V., Campo M.M., Kasapidou E., Sheard P.R., Enser M., 2003. Fffects of fatty acids on meat quality: a review. Meat Sci. 66, 21-32

\section{STRESZCZENIE}

Ograniczone żywienic i olej Iniany jako czynniki modyfikujące profil kwasów tluszczowych wieprzowiny

W doświadczeniu przeprowadzonym na 32 tucznikach badano profil kwasów tłuszczowych w thuszczu mięśniowym jako funkcję żywienia ograniczonego i dodatku oleju Inianego do dawki. Dwie grupy luczników żywiono semi ad libitum (A) w calym okresie tuczu (22-102 kg), dwom podawano ograniczoną ilość paszy $(-25 \%)$ w picrwszym okresic $(22-60 \mathrm{~kg})$ tuczu $(\mathrm{R})$, a semi ad libitum $w$ drugim okresie. W każdej z par grup w drugim okresie tuczu jedna otrzymywała dodatek $4 \%$ oleju Inianego (O), a druga $0 \%$ (C). Po uboju w mięśniach longissimus dorsi i semimembranosus oznaczano prolil kwasów tłuszczowych. Stosunek PUFA n-6:n-3 byl nieco lepszy $w$ thuszczu miçśniowym świń żywionych ograniczona ilością paszy niż żywionych semi ad libitum, alc różnice nie były statystycznie istotne. Dodatek $4 \%$ oleju lnianego do paszy w drugim okresie tuczu spowodował zwiększenie zawartości PUFA, zwlaszcza n-3. 